\title{
DERMANYSSUS GALLINAE ERADICATION APPROACH - APPLICATION OF INERT COMPOUNDS AND INTEGRAL ANIMAL HEALTH PROTECTION
}

\author{
Aleksandar Pavlićević ${ }^{*}$, Radomir Ratajac ${ }^{2}$, \\ Danijela Horvatek Tomićs ${ }^{3}$, Igor Stojanov ${ }^{2}$, Ivan Pavlović ${ }^{4}$ \\ ${ }^{1}$ AVES MIT DOO, Cluster "Dermanyssus gallinae”, Subotica-Bajmok, Serbia \\ ${ }^{2}$ Scientific Veterinary Institute "Novi Sad", Novi Sad, Serbia, \\ ${ }^{3}$ Faculty of veterinary medicine, University of Zagreb, Croatia, \\ ${ }^{4}$ Scientific Veterinary Institute Serbia, Belgrade, Serbia
}

\section{Abstract}

The generally accepted approach to D. gallinae control is based on the control of infestations. The reduction of $D$. gallinae infection to an acceptable level can temporarily prevent its harmful effects on the health status of poultry. However, the reduced number of D. gallinae continues to persist in poultry environment resulting in an intensive increase of infestation rate and consequent transmission of infectious and contagious diseases. Contrary to suppression, the eradication approach completely eliminates $D$. gallinae thus improving general health status of the flock and providing the control of infectious and contagious diseases associated with this organism and eliminating other adverse effects. Biological efficiency and selection of inert compounds was performed in laboratory conditions. The previous experience with application of $\mathrm{SiO} 2$ formulations in practice confirmed the possibility of successful eradication in 8 cases (combined application of liquid and powdered form). New generation of inert compounds (P 547/17) showed a range of superior properties as compared with $\mathrm{SiO} 2$ formulations, especially in view of high and long-lasting residual effects on non-absorbent surfaces. In laboratory conditions, after 7 months, the layer formed by a $20 \%$ working emulsion on a metal substrate exhibited efficiency of $92 \%$ after 1-hour exposure. In clinical conditions, the presence of mites was not detected even after 6.5 months of the settlement of the flock. Clinical tests of inert oils are still ongoing, but their high potential for the eradication of $D$. gallinae The eradication of D. gallinae is highly complex procedure, which

${ }^{1 *}$ Corresponding author: zemljadrveca@gmail.com 
cannot be performed at all times and in all conditions. The conditions for the eradication of D. gallinae using inert compounds include adequate hygienic preparation of the facilities while still empty, adequate application of selected compounds, and then adequate ambient temperatures which leads to increase of mites activity. The program of $D$. gallinae control includes procedures for the preparation, implementation, eradication checks, and prevention of re-infestation.

Keywords: Dermanyssus gallinae, inert formulations, eradication

\title{
PRISTUP ERADIKACIJE DERMANYSSUS GALLINAE, PRIMENA INERTNIH JEDINjENjA I INTEGRALNA ZDRAVSTVENA ZAŠTITA ŽIVINE
}

\author{
Aleksandar Pavlićevićn ${ }^{1}$, Radomir Ratajac ${ }^{2}$, \\ Danijela Horvatek Tomićs ${ }^{3}$, Igor Stojanov ${ }^{2}$, Ivan Pavlović ${ }^{4}$ \\ ${ }^{1}$ AVES MIT doo, Klaster "Dermanyssus gallinae”, Subotica Bajmok, Srbija \\ ${ }^{2}$ Naučni institut za veterinarstvo "Novi Sad”, Novi Sad, Srbija \\ ${ }^{3}$ Fakultet veterinarske medicine Zagreb, Zagreb, Hrvatska \\ ${ }^{4}$ Naučni institut za veterinarstvo Srbije, Beograd, Srbija
}

\section{Kratak sadržaj}

Opšte uvažen pristup kontrole D. gallinae zasniva se na suzbijanju infestacija. Suzbijanje D. gallinae smanjuje infestaciju na prihvatliiv nivo i privremeno sprečava značajan uticaj na zdravstveni status živine. Međutim, smanjeni broj D. gallinae nastavlja da perzistira u ambijentu i infestacija intenzivno raste, ostavljajući i dalje mogućnost prenosa infektivnih i zaraznih bolesti. Za razliku od suzbijanja, pristup eradikacije u potpunosti eliminiše $D$. gallinae, a time i uticaj na opšti zdravstveni status jata, ostvaruje važnu pretpostavku u kontroli infektivnih, posebno zaraznih bolesti (koje ona prenosi), ali i otklanja sve druge štetne posledice. U laboratorijskim uslovima utvrđena je biološka efikasnost i izvršen izbor inertnih jedinjenja. Dosadašnje iskustvo praktične primene $\mathrm{SiO} 2$ formulacija, potvrdila su mogućnost uspešne eradikacije u 8 slučajeva (kombinovana aplikacija tečnog i praškastog oblika). Nova generacija inertnih jedinjenja (P 547/17) pokazuje niz naprednijih osobina od SiO2 formulacija, posebno visoko i dugotrajno rezidualno dejstvo na ne upijajućim površinama. Sloj 
koji je formirala $20 \%$ radna emulzija na limenoj podlozi, u laboratorijskim uslovima, nakon 7 meseci ispoljava efikasnost od 92\%, u ekspoziciji od 1 sat. U kliničkim uslovima, i nakon 6,5 meseci od naseljavanja jata nije detektovano prisustvo grinja. I ako su klinička ispitivanja nove generacije inertnih jedinjenja još u toku, već sada je evidentno da imaju potencijal za eradikaciju. Eradikacija D. gallinae je zahtevan postupak kojeg nije moguće izvesti u svakom momentu i svim uslovima. Uslovi za eradikaciju D. gallinae inertnim jedinjenjima je higijenska priprema praznih objekata, adekvatna primena izabranih jedinjenja, i zatim adekvatna ambijentalna temperature koja dovodi do povećane aktivnosti grinja. Programska kontrola D. gallinae obuhvata postupke pripreme, sprovođenja, provere eradikacije i sprečavanja reinfestacije.

Ključne reči: Dermanyssus gallinae, inertne formulacije, eradikacija

\section{INTRODUCTION}

More than ever before, poultry farming is faced with the problem of poultry red mite (D. gallinae) control. When it comes to the effect on poultry, $D$. gallinae (Figure 1.) directly endangers the health status and at the same time transfers a number of infectious and communicable diseases.

Directly, feeding on blood, D. gallinae causes stress and anaemia, disrupts the immune response, transfers diseases, contributes to cannibalism and diminishes the general health status. Stress is clinically visible through the agitation of poultry, and it can also resemble nervous disorder, if D. gallinae enters the outer ear canal (Simic and Zivkovic, 1958). Somatic and psychogenic stress has been diagnosed through a blood analysis (Kowalski and Sokol, 2009). The manifestation of anaemia depends on the intensity of the D. gallinae infestation, age of the flock, nutrition and general health status of the flock. It has been established that with medium infestation, the number of mites per hen is 25000 - 50000 with the possibility of reaching 250000 . A hen infested with $D$. gallinae can lose $3 \%$ of the total amount of blood every night, and as far as $5 \%$ with an extremely high number of D. gallinae (Emous, 2005). A blood analysis of infested poultry has established a severe decrease of erythrocytes, from 3.1 million to 1.2 million (Babic et al., 1956) and damages to humoral immunity (Kowalski and Sokol, 2009). 


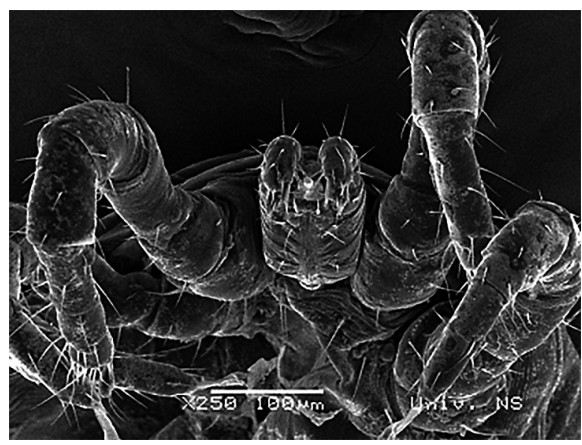

Figure 1. D. gallinae (SME, Photo Bokorov and Pavlićević)

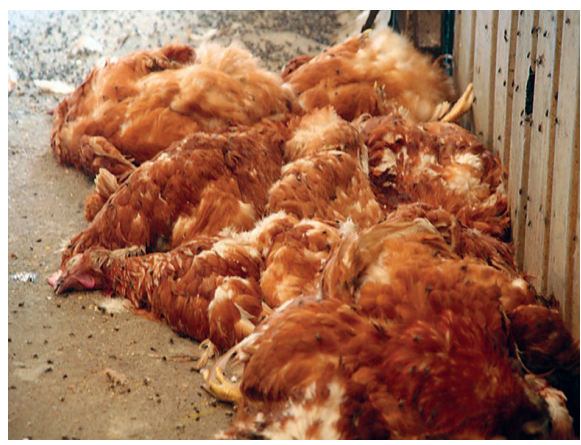

Figure 2 . Hen mortality caused by co-effect of D. gallinae and Salmonella spp. (Photo Pavlićević)

The role of $D$. gallinae as a vector is complex: it is mechanic, trans-stadial and trans-ovarian (Moro et al., 2005). So far, it is known that D. gallinae transfers Fowl pox virus (Huong et al., 2014), St Louis encephalitis (SLE) and Eastern equine encephalitis (EEE) (Durden et al., 1993); Western equine encephalitis virus (WEE) (Durden et al., 1993; Mullen and Durden, 2002; Moro et al., 2005); Newcastle disease virus, tick borne encephalitis virus or hantaviruses, and type A influenza virus (Sommer, 2011); Salmonella galinnarum and S. enteritidis (Moro et al., 2007, 2009) (Figure 2.); Escherichia coli and Erysipelothrix rhusiopathiae (Chirico et al., 2003); Pasteurella multocida (Petrov, 1975); Mycoplasma synoviae and Mycoplasma gallisepticum (Huong et al., 2014); Rickettsia spp., Spirocheta spp., Chlamydia spp. and Mycobacterium spp. (De Luna et al., 2008); Coxiella Burnetii, protozoa and filaria (Moro et al., 2005).

The widely recognized approach to the control of $D$. gallinae is based on suppressing the infestation. Suppression of $D$. gallinae temporarily prevents substantial impact on the health status and reduces infestation to an acceptable level. However, the decreased number of $D$. gallinae continues to persist in the environment and the infestation grows intensely, leaving the possibility of transfer of infectious and communicable diseases. Therefore, the harmful impact of D. gallinae on the flock re-emerges.

The aim of this research is application of selected inert substances to establish the feasibility and importance of poultry red mite eradication in laboratory and practical conditions of intense poultry keeping, and to explain its potential contribution to integrated health protection. 


\section{MATERIALS AND METHODS}

Laboratory examination was performed using Petri dish and tin boxes method on laboratory mite specimens. Clinical examination encompassed controlled application and expert monitoring, by conducting detection measures (Pavlićević, 2007a, 2017a) on a monthly basis until the end of the production year. Examinations have been conducted in the period between 2016 and 2018.

\section{RESULTS}

The results of laboratory examination of selected inert formulation are presented in Table 1. In Table 2, the results of clinical examination for selected inert formulations on farms of layers of consumer eggs in cage systems are shown.

Table 1. The results of laboratory examination of selected inert formulation: natural diatomaceous earth (DE), $\mathrm{SiO} 2$ formulations for liquid application in plastic Petri cups and formulations with inert oils (P 547/17) in tin boxes.

\begin{tabular}{|c|c|c|c|c|c|c|c|}
\hline \multirow{2}{*}{ No } & \multirow{2}{*}{ Formula, other } & \multirow{2}{*}{$\begin{array}{c}\text { Exposure } \\
1 \text { (min./hr) }\end{array}$} & \multicolumn{5}{|c|}{ Day of results collection, efficacy (\%) } \\
\hline & & & 1. & 2. & 3. & 4. & 5. \\
\hline \multirow{2}{*}{1} & \multirow{2}{*}{$\begin{array}{l}\text { Natural DE, } \\
\text { powdered form }\end{array}$} & $\min$. & 12 & 25 & 79 & 98 & - \\
\hline & & hr. & 33 & 46 & 89 & 98 & - \\
\hline \multirow{2}{*}{2} & \multirow{2}{*}{$\begin{array}{l}\text { Natural DE, } \\
\text { powdered form }\end{array}$} & $\min$. & 92 & 100 & - & - & - \\
\hline & & hr. & 99 & 100 & - & - & - \\
\hline \multirow{2}{*}{3} & \multirow{2}{*}{$\begin{array}{l}\mathrm{SiO} 2 \text { product, } \\
\text { liquid form }\end{array}$} & $\min$. & 85 & 91 & - & - & - \\
\hline & & hr. & 37 & 78 & 88 & 97 & 100 \\
\hline \multirow{2}{*}{4} & \multirow{2}{*}{ P 547/17 } & $\min$. & 100 & - & - & - & - \\
\hline & & hr. & 100 & - & - & - & - \\
\hline 5 & $\begin{array}{l}\text { P 547/17 re- } \\
\text { sidual effect } \\
4 \text { months }\end{array}$ & hr. & 99 & - & - & - & - \\
\hline 6 & $\begin{array}{l}\text { P 547/17 re- } \\
\text { sidual effect } \\
4 \text { months }\end{array}$ & hr. & 92 & - & - & - & - \\
\hline
\end{tabular}


Table 2. The results of some clinical examination for selected inert formulations on farms of layers of consumer eggs in cage systems: Numbers: 1-11 combined application of powdered and liquid forms of SiO2 formulations, No.: 12-14 inert oils P 547/17

\begin{tabular}{|c|c|c|c|c|}
\hline No. & $\begin{array}{c}\text { Capacity } \\
\text { of facility }\end{array}$ & Product & $\begin{array}{c}\text { Duration } \\
\text { of sup- } \\
\text { pression } \\
\text { (months) }\end{array}$ & $\begin{array}{c}\text { Find- } \\
\text { ing (-/+) } \\
\text { (months) }\end{array}$ \\
\hline 1 & 2500 & Comb. SiO2, no. $(1+3)^{\star}$ & 12 & $12(-)$ \\
\hline 2 & 25000 & Comb. SiO2, no. $(2+3)$ & 12 & $12(-)$ \\
\hline 3 & 25000 & Comb. SiO2, no. $(2+3)$ & 12 & $12(-)$ \\
\hline 4 & 25000 & Comb. SiO2, no. $(2+3)$ & 12 & $12(-)$ \\
\hline 5 & 25000 & Comb. SiO2, no. $(2+3)$ & 12 & $12(-)$ \\
\hline 6 & 25000 & Comb. SiO2, no. $(2+3)$ & 12 & $12(-)$ \\
\hline 7 & 25000 & Comb. SiO2, no.(2+3) & 12 & $12(-)$ \\
\hline 8 & 25000 & Comb. SiO2, no. (2+3) & 12 & $12(-)$ \\
\hline 9 & 12000 & Comb. SiO2, no. (1+3) & 12 & $12(+)$ \\
\hline 10 & 40000 & Comb. SiO2, no. (2+3) & 12 & $12(+)$ \\
\hline 11 & 18000 & Comb. SiO2, no. (2+3) & 12 & $12(+)$ \\
\hline 12 & 2000 & P 547/17 (15\%) & Pending & $6,5(-)$ \\
\hline 13 & 4500 & P 547/17 (15\%) & Pending & $6,5(-)$ \\
\hline 14 & 20000 & P 547/17 (20\%) & Pending & $6(-)$ \\
\hline
\end{tabular}

* Represent No. of products from Table 1, which is used for combined application.

\section{DISCUSSION}

Although this examination has been primarily focused on the poultry health status aspect of D. gallinae control, it also includes the basic elements of the general review of the topic.

The first task in setting down D. gallinae control measures is determining the aim of this control. When reviewing the sources of information in $D$. gallinae control, we have noticed that this issue has not been given adequate attention, or that is has been simply claimed that eradication is not possible. With the lack of adequate guidance, the generally accepted practice of D. gallinae control is based on suppression. 
If the suppression is set as a goal of D. gallinae control, it is associated with the following: (1) regular annual expenses for farmers for D. gallinae control, which also grow each year (Emous, 2005, 2017), while postponing other harms (best case) or simply both of these together (probably most common); (2) constant presence of parasites, i.e., vectors in the facility; (3) an evident toxicological risk (uncritical control); (4) spreading (prevalence points to a long-term adverse tendency of the disease).

Eradication of D. gallinae from production facilities (1) eliminates the toxicological risk that arises from inadequate D. gallinae control; (2) eliminates the role of $D$. gallinae vectors; (3) eliminates the harmful effect of $D$. gallinae on the health status of the flock; (4) greatly protects the farmers' economic interest; (5) greatly protects the health and economic interests of the consumers; (6) greatly protects the interests of farm staff; (7) prevents the development of resistance; (8) prevents further expansion of dermanyssosis. These reasons justify eradication.

The feasibility of $D$. gallinae eradication in practical conditions was proven in 2000 in Serbia. Eradication was possible with selected synthetic chemical neurotoxic compounds, acaricides (insecticides). Apart from the basic biological efficacy, it was important to define the level of chemoresistance (Pavlićević et al., 2016). Synthetic chemical neurotoxic compounds are associated with toxicological risks. In order to eliminate them it was necessary to find another option, which would meet the requirements of biological efficacy and rational application. Theoretical analysis as well as comparative laboratory and clinical testing have established the prospective of using selected inert substances in the control of D. gallinae.

In laboratory environment, inert substances are selected according to the requirements of biological efficacy and a particularly pronounced residual effect. Apart from this, we have also established their deficiencies and limitations. The optimized use has been achieved by combining the powdered and liquid forms of $\mathrm{SiO} 2$, and has successfully confirmed the possibility of eradication by using inert formulations (Figure 3.). Potential limitations of inert formulations for achieving biological efficacy in clinical practice are poor environmental conditions. With the improvement of the product (P 547/17) can be expected to reduce the environmental impact on product efficiency.

Eradication of D. gallinae using the aforementioned inert substances is not possible at any time and in all conditions. The conditions for eradication using inert substance include the following: (1) an empty facility; (2) selection of appropriate and efficient formulation, which should be properly applied; (3) proper hygienic conditions; (4) rest period for facility and (5) adequate 
temperature conditions. The approach of introducing all necessary measures for D. gallinae control to an empty facility and preventing any harmful effect on the flock is immensely important issue of preventive veterinary medicine. Inert formulations differ according to their biological efficacy, so their selection ought to be established in advance. Hygienic conditions (Figure 4.) and an empty facility allow for ideal direct contact with $D$. gallinae population, but also an ideal contact with the surfaces on which a layer with a prolonged effect is to be formed.

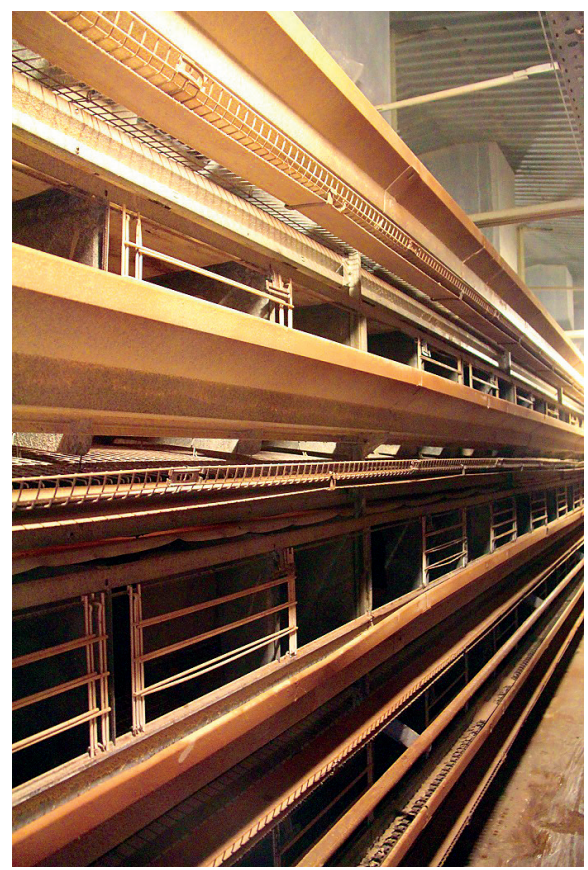

Figure 3. Example of a successfully prepared facility by means of a combined $\mathrm{SiO} 2$ treatment (Photo Pavlićević).

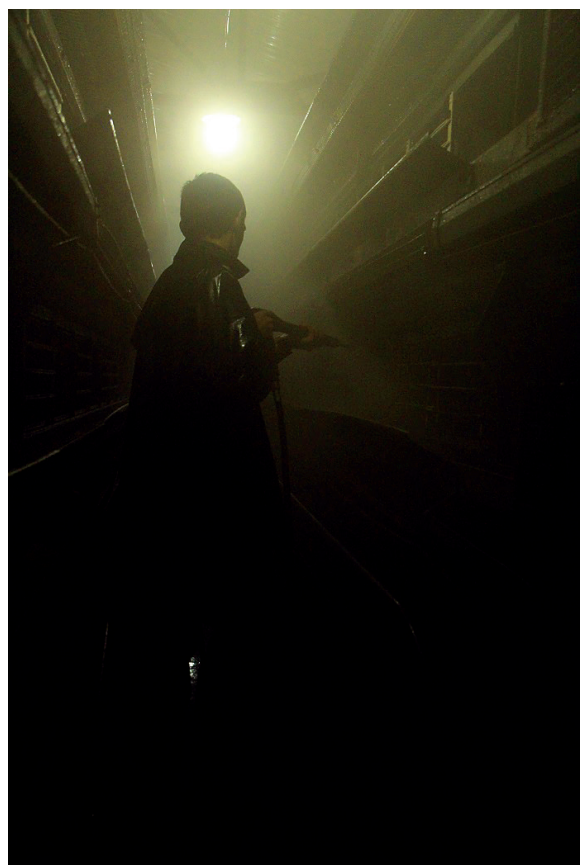

Figure 4. Hygienic preparation, washing the facility with puromate (Photo Pavlićević).

The use of inert substances is highly demanding in terms of hygiene conditions. The currently used technology of poultry keeping is of utmost importance for the success of disinfection. Facility rest period in temperature conditions for mite activity incites $D$. gallinae to leave its hiding places in search of food, thus becoming exposed to the prolonged effect of the inert layer. In time, the infestation is exhausted and finally exterminated. Higher temperatures enhance the procedure and also reduce the necessary break period. 
The new generation of inert substances is applied in the form of water emulsion (P 547/17) (Figure 5.). Their use highly improves the most important aspect of $D$. gallinae control, that is, residual effect on non-absorbent surfaces. To the best of our knowledge, such strong residual effect on D. gallinae ( $92 \%$ efficiency with 1 hour exposure, after 7 months in laboratory conditions) has not been reported so far. The first test suggests eradication potential, but for absorbent surfaces (e.g. concrete) repeated treatment is required, because on these surfaces, it is not possible to achieve an extended effect with one treatment.

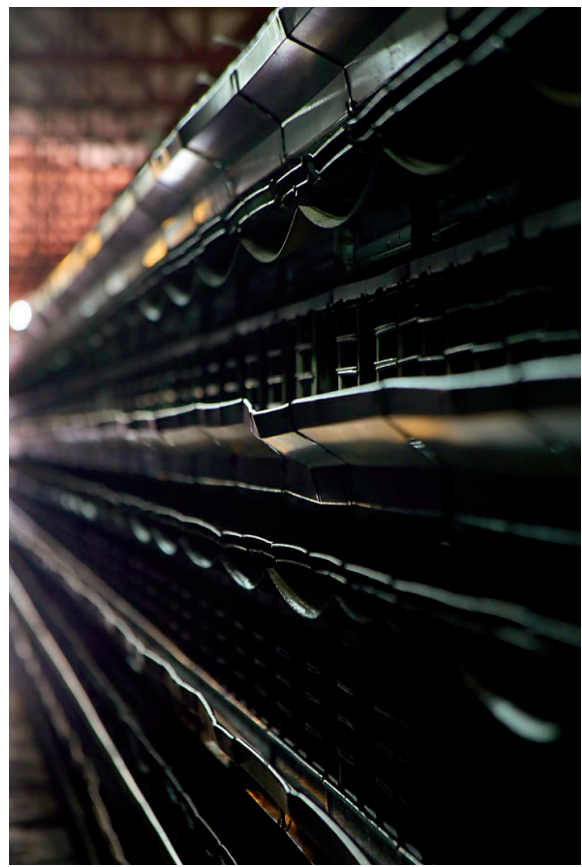

Figure 5. An example of a facility prepared with the new generation of inert substances $(\mathrm{P}$ 547/17) (Photo Pavlićević).

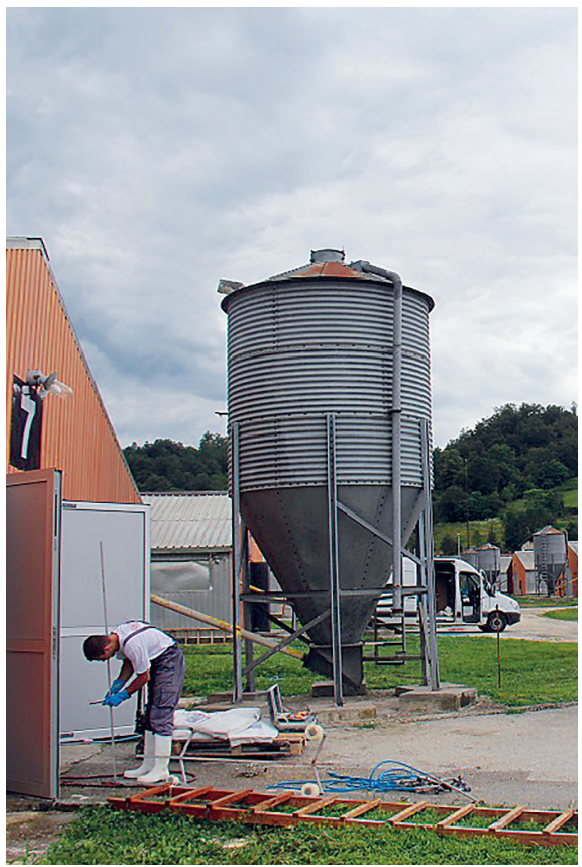

Figure 6. An example of the successful eradication of D. gallinae by combined $\mathrm{SiO} 2$ method, the farm "Boksiti, Milići", Republic of Srpska, Bosnia and Herzegovina (Photo Pavlićević).

The safety is thus ensured in a twofold manner, with the application itself and the type of formulation. Application in an empty facility eliminates the possibility of direct exposure to application and stress of the poultry, and minimizes contact level. In this way, neither the diatomaceous earth has any 
significant influence. Inert substances of the new generation are practically non-toxic (Perić, 2018). Eradication of D. gallinae completely eliminates (present and future) toxicological risks, which may arise from uncritical control, and especially the use of synthetic neurotoxic chemical compounds.

The test results of inert substance application (in 8 facilities) have confirmed the possibility of successful eradication. The time period of an entire annual cycle and the envisaged exploitation detection, has undeniably confirmed the reliability of eradication findings. In certain cases (in 3 facilities) there was no eradication, but these still presented examples of efficient suppression with mere preparation of the facility that could be eradicated with very little attention.

Clinical examinations are influenced by a multiplicity of factors, which we were not able to uniformly ensure, control or strictly define on this occasion. According to the results of laboratory examination, the very factor of facility rest period of one year is not sufficient for D. gallinae eradication (Pavlićević, 2007), but a one-month rest period in the summer period along with the appropriate application of selected inert formulations can enable eradication. Since the influencing factors will need to be more closely defined, the efficient suppression ought to be the first step in the systematic approach to the control program. This way, the toxicological risk is removed; health and economic damages are reduced and gradually, as possibilities are created it would be possible to perform eradication in the facilities, i.e., farms.

To successfully conduct eradication and maintain its full potential, it is necessary to take a comprehensive and thorough program-approach. The program for the control of D. gallinae includes the following components: data base, analysis and definition of a logic control approach; rational selection of methods and products; active role of farmers; preparations for the procedure; optimisation of application; eradication control; eradication audit as well as prevention of the re-infestation by introducing biosecurity measures; affirming a wide and preventive information base. Biosecurity measures are important within the farm and especially in relation to external environment. Eradication conducted using $\mathrm{SiO} 2$ formulations will be invalidated if a new flock or transportation cages are infested on a high level.

An important part of the problem is the statement that farmers' orientation towards selecting a product can be exclusively economically motivated (Anon, 2017). This situation demands the veterinary professionals to educate farmers about the technological process for the preparation of a new flock, which they will be required to adhere to, thus ensuring an adequate basis for the control of D. gallinae and protection of general health status of poultry. An opportunity for the latter is introducing the control of D. gallinae, being an 
important vector, to the program control measures for related communicable diseases. In this way, the facility rest period applied as a measure in the control of communicable diseases could simultaneously be used for the control of $D$. gallinae (Pavlićević et al., 2017).

Apart from this, eradication should be one of the criteria for classification of communicable diseases which should be reported. Required reporting of Dermanyssosis would enable: (1) the protection of not infested farms by implementing relevant biosecurity measures; (2) interest-driven direction of farmers; (3) establishing and monitoring the exact prevalence (if applicable with intensity and extensity of $D$. gallinae infestation); (4) improving toxicological risks prevention; (5) contributing to the systematic control approach; (6) affirming integrated health protection.

Mandatory reporting and implementation of measures and recommendations for technological procedure into the program for communicable diseases (for which it is a vector), would create the conditions for a systematic application of the control program. Eradication of D. gallinae from production facilities would lead to the cessation of adverse tendencies of Dermanyssosis, health risks and great economic damages. From an economic perspective, the suggested approach can easily be reviewed if we consider the example of a producer with the capacity of 100.000 hens and an estimation of an annual expense of 0.60 Euro per hen (Emos, 2017). In a ten year period, the money savings would be 600.000 Eur.

So far, clinical examinations have been conducted on farms with conventional cages (Figure 6.). Pending examinations are in facilities with enriched cages, which require modification of the procedure. Examinations in aviaries have not yet been conducted, and specific modifications of the program can give successful results. However, organic poultry production and contact with wild birds pose specific challenge. Only future examinations could provide an insight in such situations. For micro producers, who keep poultry in the open, we recommend an alternative approach to D. gallinae control rather than eradication (P- 2017/0762).

\section{CONCLUSION}

Making eradication the final aim of D. gallinae control is technically conceivable. Inert formulations enable a safe and manifold useful procedure. The emphasis is laid on preventive veterinary medicine and its capacity of preventing Dermanyssosis tendencies in poultry farming by eliminating harmful consequences and sustaining the integrated health protection. 


\section{REFERENCES}

1. Anon: Poultry Red Mite Expert Roundtable. Proceedings Booklet. Prepared by Novometrix Research Inc. MSD Animal Health, 2017.

2. Babić I., Delak M., Mikačić D.: Nametnici i nametničke bolesti domaće peradi; Jugoslovenska akademija znanosti i umetnosti, Zagreb; 259-328, 1956.

3. Chirico J., Eriksson H., Fossum O., Jansson D.: The poultry red mite, Dermanyssus gallinae, a potential vector of Erysipelothrix rhusiopathiae causing erysipelas in hens. Medical and Veterinary Entomology, 17, 232-234, 2003.

4. De Luna C.J., Arkle S., Harrington D., George D.R., Guy J.H., Sparagano O.A.: The poultry red mite Dermanyssus gallinae as a potential carrier of vector-borne diseases. Annals of the New York Academy of Sciences, 1149, 255-8, 2008.

5. Durden L.A., Linthicum K.J., Monath T.P.: Laboratory transmission of eastern equine encephalomyelitis virus to chickens by chicken mites (Acari: Dermanyssus). Journal of Medical Entomology, 30, 1; 281-5, 1993.

6. Emous Van R.: Verwachtte schade bloedluis 21 miljoen euro. Pluimveeweb. nl. 2017. https://www.pluimveeweb.nl/artikelen/2017/01/schade-bloedluis21-miljoen-euro/. Accessed 17 Jan 2017.

7. Emous Van R.: Wage war against the red mite! Poultry International, 44, 11, 26-33, 2005.

8. Huong C.T.T., Murano T., Uno Y., Usuo T., Yamaguchi T.: Molecular Detection of Avian Pathogens in Poultry Red Mite (Dermanyssus gallinae) Collected in Chicken Farms. Journal of Veterinary Medical Science, 76, 1583-1587, 2014.

9. Kowalski A., Sokol R.: Influence of Dermanyssus gallinae (poultry red mite) invasion on the plasma levels of corticosterone, catecholamines and proteins in layer hens. Polish Journal of Veterinary Sciences, 12, 2, 231-5, 2009.

10. Moro C.V., De Luna C.J., Tod A., Guy J.H., Zenner L., Sparagano O.A.E.: Pathogens and symbionts associated with Dermanyssus gallinae: risks and potential control methods for the poultry industry. Poultry Welfare Symposium Cervia, Italy, 18-22 May, 2009, 86.

11. Moro Valiente C., Chauve C., Zenner L.: Vectorial role of some Dermanossoid mites (Acari, Mesostigmata, Dermanyssoidea). Parasite, 12, 99109, 2005.

12. Moro Valiente C., Fravalo P, Amelot M, Claude C, Salvat G, Lionel Z.: Infection transmission experimentales de Salmonella enteritidis par le pou rouge des volailles Dermanyssus gallinae. Septièmes Journées de la Recherche Avicole, Tours, 28-29 March, 2007, 319-323. 
13. Mullen G., Durden L.: Medical and Veterinary Entomology; Academic press, 2002.

14. Pavlićević A., JongUng Yoon, Pavlović I., Milanović M., Petrović T.: Kontrola Dermanyssus gallinae i program mera kontrole zaraznih bolesti predlog integralne zdravstvene zaštite. XIX Simpozijum epizitiologa i epidemiologa 05.-07.03.2017, Vršac, Srbija, 2017, 171-172.

15. Pavlićević A., Pavlović I., Dotlić M.: A contribution to information on starvation survival capacity of poultry red mite Dermanyssus gallinae. Lucrari Stiintifice Medicina Veterinara, 50, 9, 485-491, 2007.

16. Pavlićević A., Pavlović I., Stajković N., Bratislav P.: Evidence for Resistance to Carbaryl in Poultry Red Mites from the Republic of Serbia and Montenegro. Scientific Papers: Animal Science and Biotechnologies, 49, 1, 222-225, 2016.

17. Pavlićević A., Pavlović I., Stajković N.: Method for early detection of poultry red mite Dermanyssus gallinae (DeGeer, 1778). Biotechnology in Animal Husbandry, 23 (3-4), 119-127, 2007 a.

18. Pavlićević A., Pavlović I., Vasić A., Pavlović I., JongUng Yoon., Beatriz Chueca.: Detección temprana del ácaro rojo. Albéitar: publicacion veterinaria independiente (Esp), 205, 36-38, 2017a.

19. Perić A: Toksikološka ocena. National Poison Control Centre. Int.br. 1121, 17.01.2018. Vojno-medicinska akademija, Beograd, Srbija. Stručna komisija: Jasmina Jović, Slavica Vučinić i Vesna Jačević, 2018.

20. Petrov D.: Study on the gamasid red mite of poultry, Dermanyssus gallinae, a carrier of Pasteurella multocida. Vet Med Nauki, 12, 32-36, 1975

21. Simić Č., Živkovic V.: Artropodi paraziti čoveka i domaćih životinja, Medicinska knjiga, Beograd - Zagreb, 1958.

22. Sommer D.S.: Die Rote Vogelmilbe, Dermanyssus gallinae DE GEER, 1778, ein experimentell nachgewiesener mechanischer Vektor von Influenza AVirus und Versuche zur Bekämpfung der Roten Vogelmilbe mit einem Phenolderivat. Inaugural-Dissertation zur Erlangung des Grades eines Dr. med. vet.beim Fachbereich Veterinärmedizin der Justus-Liebig-Universität, Gießen, 2011.

Primljeno: 13.03.2018.

Odobreno: 03.06.2018. 
